\title{
Antibody to hepatitis $C$ virus in multiply transfused patients with thalassaemia major
}

\author{
B Wonke, A V Hoffbrand, D Brown, G Dusheiko
}

\begin{abstract}
Seventeen of $73(23 \cdot 2 \%)$ multiply transfused patients with thalassaemia major (age range, 1-39 years) tested positive for antibody to hepatitis $\mathrm{C}$ virus (anti-HCV). Eleven of the 24 patients regularly transfused in countries outside Britain were anti-HCV seropositive; only six of the 49 regularly transfused in Britain were seropositive. The incidence of anti-HBs and anti-HBc was similar to that of antiHCV in both the British and foreign patients. The anti-HCV seropositive patients showed significantly higher plasma aspartate aminotransferase activities (AST), mean (SD) $10.2(70.3)$ $U / 1$, and serum ferritin concentrations, 4067 (2708) $\mu \mathrm{g} / \mathrm{l}$, than the anti-HCV seronegative patients (AST, 33.9 (15.6) $U / 1$; serum ferritin 2051 (2092) $U / 1)$, respectively. Among the 36 patients who had earlier undergone liver biopsy 10 of 21 with histological features of chronic active hepatitis or cirrhosis, or both, were seropositive for anti-HCV whereas only one of 15 without histological evidence of chronic viral hepatitis was seropositive for anti-HCV.

It is concluded that $\mathrm{HCV}$ is a major cause of chronic hepatitis in patients with thalassaemia major and is associated with raised AST activity and serum ferritin concentration compared with patients seronegative for anti-HCV.
\end{abstract}

Patients with thalassaemia major are at a high risk of developing hepatitis due to the transfusion of blood from donors infected with hepatitis $B$ virus (HBV). The incidence of hepatitis $\mathbf{B}$ infections based on serological studies approaches $100 \%$ in thalassaemia major where HBV is endemic. ${ }^{1}$ Some patients develop clinical and liver biopsy appearances of viral hepatitis without laboratory evidence of hepatitis B or hepatitis A infections, and have been considered to be infected with another virus, non-A, non-B (NANB) hepatitis. Recently, a parenterally transmitted hepatitis virus has been molecularly cloned and the virus termed hepatitis $C$ virus $(\mathrm{HCV}){ }^{2}$ It is now possible to detect antibodies to a protein antigen of $\mathrm{HCV}$ and this forms the basis of specific radioimmunoassay and enzyme linked immunosorbent assay (ELISA) for HCV infection. ${ }^{3}$ The incidence of this antibody in normal blood donors, blood transfusion recipients with post-transfusion NANB hepatitis, and in other high risk groups, including patients with chronic hepatitis, haemophilia, intravenous drug abusers, patients receiving haemodialysis and homosexual men with human immunodeficiency virus infection (HIV) has been reported recently. ${ }^{4-8}$

In this study we determined the incidence of anti-HCV in 73 multiply transfused patients with thalassaemia major and related the findings to the country of origin, age, liver function and serum ferritin concentrations and to the appearance of liver biopsy specimens.

\section{Methods}

Seventy three transfusion dependent patients with thalassaemia major were studied. They included 41 males and 32 females, and their ages ranged from 12 months to 39 years (mean $16 \cdot 2$ years). Forty nine patients received regular transfusions in Britain; their ages ranged from 12 months to 39 years (mean 19.4 years). The other 24 patients were transfused abroad (Bahrain, Hong Kong, India, Kenya, Kuwait, Northern Cyprus, Pakistan and United Arab Emirates). Their ages ranged from 2-31 years (mean 13 years). None had received hepatitis $B$ vaccination at the time of testing for anti-HBc (HB core antigen) and anti-HBs (HB surface antigen). Thirty six had undergone liver biopsy in 1985 or 1986.

Serum samples $(20 \mu \mathrm{l})$ were incubated at $37^{\circ} \mathrm{C}$ for 60 minutes in microwells coated with $\mathrm{HCV}$ recombinant antigen (Ortho Diagnostics, Raritan, New Jersey, USA). If present, anti$\mathrm{HCV}$ antibody binds to this antigen. After washing, murine monoclonal anti-human IgG conjugated to horse radish peroxidase was added and incubated at $30^{\circ} \mathrm{C}$ for 60 minutes. The wells were then washed, and $200 \mu \mathrm{l}$ of substrate (o-phenylenediamine-HCL) were added. After 30 minutes of incubation at room temperature the reaction was stopped and the oxidation colour read by measuring absorbance at a wavelength of $490 \mathrm{~nm}$. Samples were positive if the absorbance was greater than the mean of the negative controls (Ncx) $+0 \cdot 400$.

Hepatitis B surface antigen (HBsAg) was measured by immunoradioprecipitation ${ }^{9}$ and anti-HBc and anti-HBs by radioimmunoassay (Abbot, North Chicago Illinois, USA). Plasma aspartate aminotransferase (AST) was measured by autoanalysis (normal 17-40 U/1) and serum ferritin by either an immunoradiometric (Becton Dickinson) or ELISA method $^{10}$ (normal range: male $39-340 \mu \mathrm{g} / \mathrm{l}$, female 14-140 $\mu \mathrm{g} / 1)$.

Liver biopsy specimens were read by an 
Table 1 Incidence of anti-HCV and anti-HBV ( $s$ and c) among 73 patients classified according to location of transfusion

\begin{tabular}{|c|c|c|}
\hline & $\begin{array}{l}\text { Transfused in } \\
\text { Britain }\end{array}$ & $\begin{array}{l}\text { Transfused } \\
\text { abroad }\end{array}$ \\
\hline & No of patients & No of patients \\
\hline Anti-HCV + & 2 & 5 \\
\hline $\begin{array}{l}\text { Anti-HBC and anti-HBs + } \\
\text { Anti-HCV }+\end{array}$ & 4 & 6 \\
\hline $\begin{array}{l}\text { Anti-HBc and anti-HBs- } \\
\text { Anti-HCV - }\end{array}$ & 5 & 8 \\
\hline $\begin{array}{l}\text { Anti-HBc and anti-HBs + } \\
\text { Anti-HCV - } \\
\text { Anti-HBc and anti-HBs - }\end{array}$ & 38 & 5 \\
\hline Total & 49 & 24 \\
\hline
\end{tabular}

experienced hepatic histopathologist, as described previously. ${ }^{11}$ Those patients with features of either chronic persistent or chronic active hepatitis with or without cirrhosis were considered, histologically, to have chronic hepatitis.

Statistical analysis was by unpaired student's $t$ and the $\chi^{2}$ tests. All means are shown as one standard deviation (SD).

\section{Results}

Seventeen $(23.2 \%)$ of the 73 patients were antiHCV positive. The ages of the positive patients (mean 16.9, range $1.5-31$ years) were similar to these of the anti-HCV seronegative patients (mean 16.2, range 1-39 years). Of the 24 patients transfused outside Britain, 11 (45.8\%) were anti-HCV positive whereas only six $(12.2 \%)$ of the 49 patients transfused in Britain were anti-HCV positive $(\mathrm{p}<0.05)$ (table 1$)$

None of the 73 patients was $\mathrm{HBsAg}$ positive. The incidence of seropositivity for anti-HBc and anti-HBs in the anti-HCV positive patients-seven $(41 \%)$ of 17 -was higher (but not statistically so) than the incidence in the anti-HCV negative patients which was 13 $(23.2 \%)$ of 56 . None of the patients was positive for anti-HBc or anti-HBs alone (table 1).

The plasma AST activities of the 17 anti$\mathrm{HCV}$ positive patients were significantly greater than those of the anti-HCV negative patients $(p<0.001)$, and 16 of 17 anti-HCV positive patients had raised AST activities compared with only $11(19.6 \%)$ of 56 antiHCV negative patients $(p<0.05)$ (table 2$)$. Among the anti-HCV positive patients the presence of anti-HBc and anti-HBs was not associated with a difference in AST activities; among the anti-HCV negative patients, those who were anti-HBc and anti-HBs positive had

Table 2 Serum AST activities and ferritin concentration of 73 patients grouped according to hepatitis $C$ and $B$ virus serology

\begin{tabular}{|c|c|c|c|c|c|}
\hline & \multirow{2}{*}{$\begin{array}{l}\text { No of } \\
\text { patients }\end{array}$} & \multicolumn{2}{|c|}{$A S T(U / l)$} & \multicolumn{2}{|l|}{ Ferritin $(\mu g / l)$} \\
\hline & & Range & Mean & Range & Mean \\
\hline Anti-HCV + & 7 & $33-228$ & $98 \cdot 0$ & $1400-10,600$ & 4843 \\
\hline $\begin{array}{l}\text { Anti-HBc and anti HBS + } \\
\text { Anti-HCV + }\end{array}$ & 10 & 28-233 & 106 & $890-10,200$ & 3704 \\
\hline $\begin{array}{l}\text { Anti-HBc and anti HBS - } \\
\text { Anti-HCV - }\end{array}$ & 13 & $16-159$ & $56 \cdot 0$ & $300-9050$ & 2742 \\
\hline $\begin{array}{l}\text { Anti-HBc and anti HBS + } \\
\text { Anti-HCV - } \\
\text { Anti-HBc and anti HBS - }\end{array}$ & 43 & $9-120$ & $30 \cdot 5$ & $300-9200$ & 1878 \\
\hline
\end{tabular}

Table 3 Relation between liver histology (tested in 1985 or 1986) and hepatitis $C$ and $B$ virus serology (tested in 1989)

\begin{tabular}{lcc}
\hline & $\begin{array}{l}\text { Chronic } \\
\text { hepatitis }\end{array}$ & $\begin{array}{l}\text { No histological } \\
\text { features of } \\
\text { chronic hepatitis }\end{array}$ \\
\hline $\begin{array}{l}\text { Anti-HCV + } \\
\text { Anti-HBc and anti-HBs + } \\
\text { Anti-HCV + }\end{array}$ & 5 & 0 \\
$\begin{array}{l}\text { Anti-HBc and anti-HBs - } \\
\text { Anti-HCV - }\end{array}$ & 5 & 1 \\
$\begin{array}{l}\text { Anti-HBc and anti-HBs + } \\
\text { Anti-HCV - } \\
\text { Anti-HBc and anti-HBs - } \\
\text { Total }\end{array}$ & 2 & 3 \\
\hline
\end{tabular}

significantly greater AST activities $(\mathrm{p}<0.05)$ (table 2).

The patients positive only for anti-HCV also had significantly higher AST values than those positive only for anti-HBc and anti-HBs $(\mathrm{p}<0.002)$.

Of the 17 anti-HCV positive patients, 14 had persistently or fluctuatingly raised AST activities measured at three monthly intervals for the previous one to four years, two had had normal AST activities until 1986 and then showed persistently raised activities, while one had raised AST activities in 1985 and 1986 which subsequently remained in the normal range (data not shown).

The overall mean serum ferritin concentrations were also greater in the anti-HCV positive patients (mean (SD) 4173 (2810), range 890 $10600 \mu \mathrm{g} / \mathrm{l})$ than in the anti-HCV negative patients (mean (SD) 2079 (2038), range 300 $9200 \mu / 1)(\mathrm{p}<0.001)$. There was also a trend for the patients who were anti-HBc and anti-HBs positive to have higher serum ferritin concentrations than those who were negative, but these differences were not significant.

\section{LIVER BIOPSY FINDINGS}

Thirty six patients underwent liver biopsy. The correlation between the hepatitis $C$ and $B$ serology and histological evidence of chronic hepatitis are detailed in table 3 . Ten $(48 \%)$ of the 21 patients with chronic active hepatitis with or without cirrhosis were anti-HCV positive; only one $(6 \%)$ of 15 patients without these changes was anti-HCV positive $(p<$ $0 \cdot 05)$.

\section{Discussion}

The results show a pronounced difference in the incidence of anti-HCV antibody in the sera of patients with thalassaemia major according to whether regular transfusions had been carried out in Britain or in other countries where thalassaemia is prevalent. Nevertheless, the incidence of anti-HCV seropositivity $(12 \cdot 2 \%)$ among 49 locally transfused patients is substantially higher than in normal blood donors in the United Kingdom $(0 \cdot 5-1 \cdot 0 \%)^{4}$ and 3123 blood transfusion donors tested in West Germany $(0.42 \%)^{6}$ or among 290 healthy, normal subjects or pregnant women in Spain $(1.2 \%) .^{5}$ The incidence of seropositivity for anti-HCV in our entire patient population or in the British group of thalassaemic patients considered alone did not correlate with the 
age (and therefore number of transfusions received).

A recent report, albeit in a Spanish population, ${ }^{5}$ shows a higher incidence of antiHCV than we found in our thalassaemic patients, haemophilic patients $(70 \%)$, intravenous drug abusers $(70 \%)$, and in patients with chronic active hepatitis (38\%), and a comparable incidence in patients receiving haemodialysis $(20 \%)$, with a lower incidence in homosexual men seropositive for $\operatorname{HIV}\left(8^{\circ} \%\right)$.

There was a significant difference in plasma AST activities between the anti-HCV seropositive and negative cases. Anti-HCV is found more frequently in chronic than in resolving non-A, non-B hepatitis and generally indicates active viral replication and ongoing infectivity rather than convalescence. ${ }^{12}$ Our findings are also consistent with the findings of a recent study of patients in Holland two to 26 weeks after transfusion which also showed a correlation between raised AST activities and positive anti-HCV tests. ${ }^{7}$ Our data also show that 16 of the 17 anti-HCV seropositive cases had had persistently or intermittently raised plasma AST activities for one to four years before the present study, while the other patient had had raised activities three years earlier which had fallen to normal, suggesting resolution of necrosis and inflammatory liver damage.

The patients seropositive for anti-HCV also showed higher serum ferritin concentrations than the seronegative patients, although their ages and therefore transfusional iron overload were similar. Previous studies have shown that the serum ferritin concentration may be raised in chronic active hepatitis in the absence of iron overload. ${ }^{13}$ Our results show that the serum ferritin concentration is roughly doubled by ongoing chronic necrosis and inflammatory changes in patients with iron overload and chronic hepatitis $C$. This finding should be borne in mind when managing patients receiving life long transfusions if the serum ferritin concentration is used solely as a measure of degree of iron overload so that the intensity of iron chelation treatment can be adjusted accordingly. Clearly, the serum ferritin concentration should be assessed in conjunction with the HCV state and liver function, as well as other measurements of iron stores, such as the urinary iron excretion in response to the chelating agent.

We attempted to relate the viral serology of hepatitis with the appearances of liver biopsy specimens. This analysis must be interpreted with caution because the HBV serology and liver biopsies were performed in 1985-1986 ${ }^{11}$ and the anti-HCV tests in 1989 . We believed it unethical and hazardous, however, to repeat the biopsies at less than five yearly intervals in this cohort. Nevertheless, some points of interest emerge. There was a pronounced difference in the incidence of anti-HCV between the patients with histological evidence of chronic active hepatitis with or without cirrhosis $(48 \%)$ and those without these changes $(6.7 \%)$, confirming that seropositivity for anti$\mathrm{HCV}$ infection is associated with histological evidence of chronic hepatitis. It is also of interest, however, that nine of 21 patients with histologically confirmed hepatitis were negative for both hepatitis B and C markers. This could reflect the relative insensitivity of this first generation anti-HCV assay, as suggested by Van der Poel, ${ }^{7}$ or the disappearance of $\mathrm{HCV}$ antibody in the three years between the liver biopsy and the anti-HCV test. It may also be explained if a hepatotropic non-A, non-B virus other than $\mathrm{HCV}$ is responsible for the liver damage in these frequently transfused patients.

We are grateful to Professor PJ Scheuer and Dr LA Fenton for the interpretation of liver biopsy specimen and to Mrs B Jackson for the serum ferritin assays.

1 Moroni GA, Piacentini G, Terzol S, et al. Hepatitis B or non-A non-B virus infection in multitransfused thalassaemia patients. Arch Dis Child 1984;59:1127-30.

2 Choo QL, Kuo G, Weiner AJ, et al. Isolation of a cDNA clone derived from a blood borne non-A, non-B viral hepatitis genome. Science 1989;244:359-62.

3 Kuo G, Choo QL, Alter HJ, et al. An assay for circulating antibodies to a major etiologic agent of human non-A antibodies to a major etiologic agent of

4 Contreras M, Barbara JAJ. Screening of hepatitis C virus antibody. Lancet 1989;ii:505.

5 Esteban JI, Esteban R, Villadomiu L, et al. Hepatitis C virus antibodies among risk groups in Spain. Lancet 1989; ii:294-6.

6 Kuhnl P, Seidel S, Stangel W, et al. Antibody to hepatitis C virus in German blood donors. Lancet 1989;ii:324.

7 Van der Poel CL, Reesnink HW, Lelie PN, et al. Antihepatitis $C$ antibodies and non- $A$, non- $B$ post-transfusion hepatitis $C$ antibodies and non-A, non-B post-transf

8 Noel L, Guerois C, Maisonneuve P, et al. Antibodies to hepatitis C virus in haemophilia. Lancet 1989;ii:560.

9 Goodall AH, Meek FL, Waters JA, et al. A rapid one-step radiometric assay for hepatitis B surface antigen utilising radiometric assay for hepatitis B surface antigen utilising monoclonal

10 Flowers CA, Kuizon M, Beard JL, et al. A serum ferritin assay for prevalence studies of iron deficiency. Am J Hematol 1986;23:141-51.

11 Aldouri MA, Wonke B, Hoffbrand AV, et al. Iron status and hepatic disease in patients with thalassaemia major, treated with long term subcutaneous desferrioxamine. J Clin Path 1987;40:1353-9.

12 Choo QL, Kuo G, Houghton M. Hepatitis $C$ virus: the major causative agent of viral non-A, non-B hepatitis. Br Med

13 Prieto J, Barry $M$, Sherlock S. Serum ferritin in patients with iron overload and with acute and chronic liver diseases. Gastroenterol 1975;68:525-33. 